\title{
WASTE INDICATORS OF PRIMARY SECTOR AND HEALTH \& VETERINARY SERVICES FOR REGIONAL PLANNING
}

\author{
E. CIFRIAN, L. PÉREZ, E. DOSAL, J.R. VIGURI \& A. ANDRÉS \\ Chemical Engineering and Inorganic Chemistry Department, University of Cantabria, Spain.
}

\begin{abstract}
When there is a need to move smoothly and effectively from an abundance of detailed field data to summarized information, indicators and indices are used. Indicators are important tools that assist decision-makers in formulating and implementing plans for the management of waste at different geographic levels. In Cantabria, a northern Spanish region, all waste streams generated are covered through four specific Waste Plans recently adopted. The present study is focused on the Primary Sector, Health \& Veterinary Services Waste Plan (PHWP), which is the framework to the decision-making processes related to the generation and management of forest, agricultural, livestock, food industry and health \& veterinary wastes. In this work, 16 indicators have been proposed to track the evolution over time of the management of these waste streams in the region and the degree of achievement of the policy objectives. This article discusses the way to obtain, analyse and evaluate valuable information to build the indicators, finding that only eight indicators can be applied at short term. In addition, a summary of these indicators is included, showing in general, a good trend of the evolution of primary sector, health \& veterinary waste management. Finally, different actions to improve the quality of data used for the indicators development are proposed in order to obtain more useful waste indicators to the stakeholders.
\end{abstract}

Keywords: Decision-making, indicators, primary sector, regional planning, waste management, waste policy.

\section{INTRODUCTION}

Global progress towards sustainable development has originated the adoption of several sets of sustainability indicators that serve to provide information on specific environmental problems [1]. Different aspects of sustainability indicators system are emphasized for different cognition, different countries and regions, along with diverse development stages [2].

The European Environment Agency defines the concept of indicator as a measure, generally quantitative, that can be used to illustrate and communicate complex phenomena simply, including trends and progress over time $[3,4]$. Besides, indicators can be used to compare characteristics between one or more systems, and as criteria in decision-making tools [5-8]. Environmental indicators are generally used for key objectives [1,9]: (i) providing information of environmental problems; (ii) summarizing a large amount of information simplifying and harmonizing reports at various scales or levels; (iii) monitoring policies and setting priorities; (iv) assessing trends in relation to objectives and help define new ones; (v) contributing to increasing public managers on environmental issues.

For sustainable waste management plans, reliable, relevant, targeted and timely information provided by indicators and indices are important tools that assist decision-makers in formulating, implementing and assessing models, global strategies and policy measures [10,11].

The EU Waste Framework Directive [12], revised in 2008, is the cornerstone of EU waste policy. It introduced the five-step waste hierarchy, with waste prevention as the best option, followed by re-use, recycling and other forms of recovery including energy recovery. Disposal is the least preferred option. European and national regulations on waste together the elaboration of the Regional Waste Plan 2006-2010 were the context to create waste sectorial plans to be applied in the Cantabria region. Waste plans must be the regional reference for minimizing, reuse, recycling, energy recovery and disposal of waste in Cantabria, fixing specific management objectives for waste streams and the guidelines to fulfil them [13]. Four sectorial plans have been developed: (i) primary sector, 
health \& veterinary services waste; (ii) industrial, hazardous, mining, and construction and demolition waste; (iii) special waste; (iv) municipal waste.

The propose of this article is the development and application of a set of indicators for evaluating the achievement of the objectives proposed in the Primary sector, Health \& veterinary services Waste Plan in Cantabria (PHWP). The development of this set of indicators allows to obtain a systematic collection of information on the sector, on which little information is available; in the same way evolution and trends in the generation and treatment of this particular waste streams can be analysed. Besides, the information of the indicators would be used as a reference for decision-making and implementing useful tools for enhancing the primary sector, health \& veterinary waste management at the regional level.

\section{METHODOLOGY}

The region of Cantabria is a small region in the north of Spain, divided into 102 municipalities, with 592,600 inhabitants (1.3\% of Spanish population). The Gross Domestic Product (GDP) of the region is 14,027 million of Euros, which represents the $1.2 \%$ of Spanish one. Cantabria has been traditionally an agricultural region although, at the present time, this sector only represents the $4 \%$ of the GDP [14]. Primary sector generates waste streams from different sources: livestock, agriculture, forestry and food industry, which suppose a high variety of type of waste [15]. These wastes are generated in a dispersed manner, and in some cases in large quantities. The generation of some of these waste streams has become a trouble due to the separation of livestock from agriculture, where the manure was used traditionally. Most of these waste streams are managed without any control of the administration due to the non-hazardous waste character, and for this reason no databases are available.

The PHWP describe this situation and propose a series of actions and objectives to improve the management and control of these waste streams that must be evaluated [13]. To assess the achievement of these objectives, a set of indicators has been developed using a methodology based on five stages (Fig. 1) [6,16]. The main tasks of each stage are:

a. Synthesis: Indicators selection begins raising a policy question related to a group of objectives. A single indicator that answers the question is obtained.

b. Analysis: A search of data sources is required. A preliminary analysis of the system is necessary, exploring all activities developed in this matter and the responsible of them, and defining all variables and data required of each indicator. Then a systematic search of all available information is carried out, following the life cycle of these waste streams and the information flows. Finally, a catalogue of them is developed.

c. Evaluation: The indicators are evaluated under different criteria. This assessment shows the weaknesses associated with lack of available data [17,18]. Applying these criteria to define some questions (or sub-criteria) and providing a score depending on the answers (a maximum value of 16 points), the viability and feasibility of the indicators can be labelled. Criteria, subcriteria and scores used are shown in Table 1.

d. Application and interpretation: After the evaluation, the best indicator fact sheet information, containing the main characteristics, is selected. For the interpretation of results, it is necessary to calculate specific variables such as rates or ratios. The progress over time is represented graphically and, then, an analysis is performed to define the trends. Both are included in the fact sheet that also includes information that can help to give an overview of the situation such as applicable rules or guidelines. It also specifies the characteristics of its data, the calculation method, its variables and the information sources. The results obtained must be compared with the proposed objectives in the waste sectorial plan.

e. SWOT analysis: SWOT integrates internal resources of an indicator (Strengths/Weaknesses) and external environment analysis (Opportunities/Threats) under a classic strategic analysis tool for strategic management [19]. 


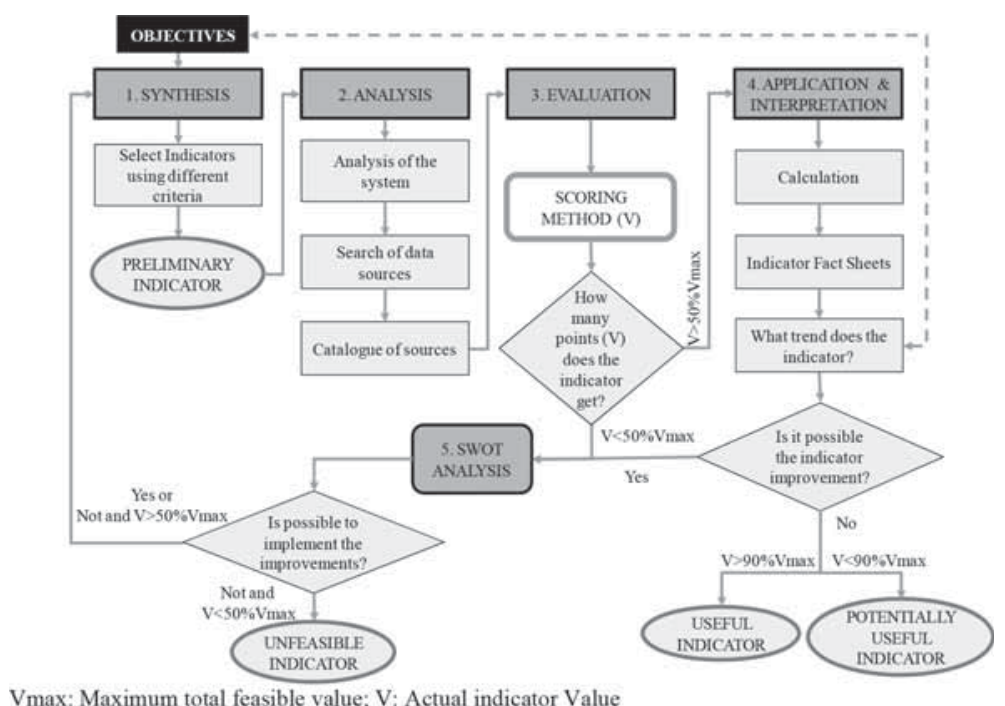

Figure 1: Methodology developed for obtaining the set of indicators. $\mathrm{V}_{\max }$ : maximum total feasible value; V: actual indicator value.

Table 1: Criteria used to evaluate indicators.

\begin{tabular}{|c|c|c|}
\hline Criteria & Questions or sub-criteria & Scoring \\
\hline $\begin{array}{l}\text { Relevant: Related to } \\
\text { goals }\end{array}$ & $\begin{array}{l}\text { Is the indicator related linked to policy } \\
\text { targets, objectives or legislation? }\end{array}$ & $\begin{array}{l}0=\text { No } \\
1=\text { Yes, indirectly } \\
2=\text { Yes, directly }\end{array}$ \\
\hline $\begin{array}{l}\text { Credible: Based on } \\
\text { complete and accurate } \\
\text { data }\end{array}$ & Are data complete and accurate? & $\begin{array}{l}0=\text { No data record } \\
1=\text { Data from various sources } \\
2=\text { Data from a single source }\end{array}$ \\
\hline $\begin{array}{l}\text { Functional: Useful in } \\
\text { decision-making }\end{array}$ & $\begin{array}{l}\text { Could the indicator provide clear and } \\
\text { easy information? }\end{array}$ & $\begin{aligned} 0= & \text { No } \\
1= & \text { Interpretation requires } \\
& \text { prior knowledge } \\
2 & =\text { Direct interpretation }\end{aligned}$ \\
\hline & $\begin{array}{l}\text { Could the indicator provide information } \\
\text { that is useful to policy decision? }\end{array}$ & $\begin{array}{l}0=\text { No } \\
2=\text { Yes }\end{array}$ \\
\hline $\begin{array}{l}\text { Quantifiable: Easiness } \\
\text { measure }\end{array}$ & Are data easily accessible? & $\begin{array}{l}0=\text { No } \\
2=\text { Yes }\end{array}$ \\
\hline & $\begin{array}{l}\text { Is the indicator based on direct or indirect } \\
\text { measurements? }\end{array}$ & $\begin{array}{l}0=\text { No data record } \\
1=\text { Estimates } \\
2=\text { Direct measurement }\end{array}$ \\
\hline \multirow[t]{2}{*}{$\begin{array}{l}\text { Comparable: Obtained } \\
\text { at different spatial and } \\
\text { temporal scales }\end{array}$} & Time series are available? & $\begin{array}{l}0=\text { No data record } \\
1=\text { No, only data points } \\
2=\text { Complete data record }\end{array}$ \\
\hline & $\begin{array}{l}\text { Is the indicator linked with other } \\
\text { indicators from the same Waste Sectorial } \\
\text { Plan? }\end{array}$ & $\begin{array}{l}0=\text { No } \\
1=\text { Qualitative link } \\
2=\text { Quantitative link }\end{array}$ \\
\hline
\end{tabular}




\subsection{Synthesis}

\section{RESULTS AND DISCUSSION}

The synthesis step was applied with the objectives proposed in the PHWP. Then, 16 indicators have been proposed, which are shown in Tables 2 and 3.

\subsection{Analysis}

To develop indicators there is a need to find quantitative and qualitative information and contribute to the possible improvement of the waste management in the region of Cantabria. So first, a literature search of previous studies is required as an aid to focus the local problems. For that, it is necessary

Table 2: Indicators associated with the proposed objectives for primary sector.

Objectives Indicator

Modernization of manure storage facilities

- Carrying out educational campaigns on the proper use of manure as fertilizer and agri-food, agricultural and livestock waste management

- Favouring the implementation of the code of good agricultural practice and statutory management requirements

- Getting economic operators participation in waste management-Establishing monitoring mechanisms to provide reliable information

- Increasing the use of biodegradable plastic

- Minimizing the generation of phytosanitary packaging waste

- Enabling enough surface to value manure

- Improvement of the agronomic potential of manure

- Reusing $100 \%$ cheese whey.-Adjustment rules of the agrifood waste and establishing monitoring mechanisms to provide reliable information

- Adjustment rules for managing livestock and agricultural waste

- Implement the management model for cleaning and disinfecting containers and plastics for agricultural use

- Increasing recovery rate of phytosanitary packaging waste

- Establishing monitoring mechanisms to provide reliable information-Increasing the recovery of residual forest biomass

- Increasing the energy production from residual forest biomass

- Promoting the use of pellets as an energy source
I-1. Degree of adaptation of manure storage facilities

I-2. Level of development of educational campaign of primary sector wastes

I-3. Degree of economic operators participation on the waste management

I-4. Level of use of biodegradable plastics

I-5. Level of generation of phytosanitary packaging waste

I-6. Rate of useful land to reuse the manure

I-7. Rate of waste recycling in food industry

I-8. Degree of management models implementation

I-9. Rate of recovery of phytosanitary packaging waste

I-10. Rate of recovery of residual forest biomass

I-11. Rate of energy production from forest biomass 
Table 3: Indicators associated with the proposed objectives for health \& veterinary services.

\begin{tabular}{|c|c|}
\hline Objectives & Indicator \\
\hline $\begin{array}{l}\text { - Correct health \& veterinary waste segregation } \\
\text { - Promoting the implementation of management } \\
\text { plans and strategies } \\
\text { - Replacing the X-ray fluids }\end{array}$ & $\begin{array}{l}\text { I-12. Selective waste collection of health \& } \\
\text { veterinary waste }\end{array}$ \\
\hline $\begin{array}{l}\text { - Promoting the staff training in health \& } \\
\text { veterinary centres }\end{array}$ & $\begin{array}{l}\text { I-13. Level of staff training in health \& } \\
\text { veterinary centres }\end{array}$ \\
\hline $\begin{array}{l}\text { - Developing regional normative for health waste } \\
\text { - Correct health \& veterinary waste segregation, } \\
\text { prevention of mixing with other waste streams }\end{array}$ & $\begin{array}{l}\text { I-14. Rate health centres that make a } \\
\text { selective collection at source }\end{array}$ \\
\hline $\begin{array}{l}\text { - Implantation of selective waste management for } \\
\text { veterinary livestock waste }\end{array}$ & $\begin{array}{l}\text { I-15. Level of development of selective waste } \\
\text { management for veterinary livestock } \\
\text { waste }\end{array}$ \\
\hline $\begin{array}{l}\text { - Management of the } 100 \% \text { health hazardous } \\
\text { waste }\end{array}$ & $\begin{array}{l}\text { I-16. Level of management of health } \\
\text { hazardous waste }\end{array}$ \\
\hline
\end{tabular}

to elaborate a catalogue of the information sources. Tables 4 and 5 show the major studios, research projects and sources of data developed in different organizations covering different geographic areas.

\subsection{Evaluation}

The indicators were evaluated based on scoring method. The results of each indicator are included in Table 6. The criteria do not determine the feasibility of the indicators, but provide the framework for asking questions and warn of the properties of the indicators [32].

However, this evaluation allows determining the potential development of these indicators. That is, eight of the indicators obtain more than 8 points $\left(\geq 50 \% \mathrm{~V}_{\max }\right)$, so these indicators have a high development potential. The rest of indicators with a score below 8 points are more complicated and time consuming to develop because the necessary data records should be created. The eight most potential indicators have already developed.

\subsection{Application and interpretation of results}

In this section, the specific variables and their progress over time for each indicator are shown.

\subsubsection{Level of use of biodegradable plastics (I-4)}

This indicator is based on the use of biodegradable plastic by farmers in Cantabria compared with conventionally used plastics. Conventional plastics are polymers that persist in nature for long periods of time and generate large amounts of waste in front of biodegradable plastics.

According to the Department of Rural Development, Livestock, Fisheries and Biodiversity of the Government of Cantabria [26], the use of conventional plastics is estimated from the number of bales used for ensiling of forage because this is the largest volume of plastics use in the primary sector in Cantabria. The use of conventional plastics is estimated to be around 140 tonnes $(200,000$ 


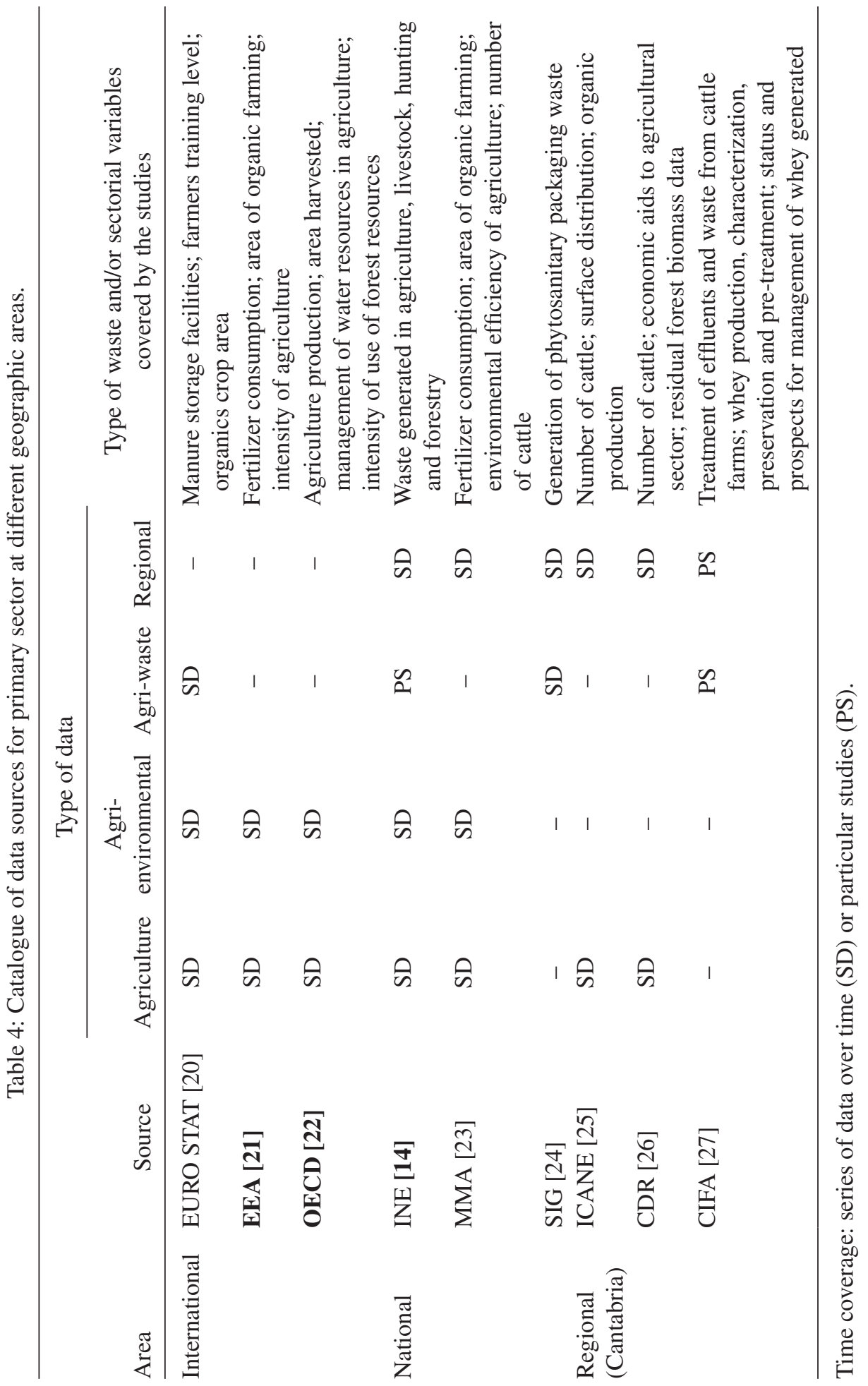




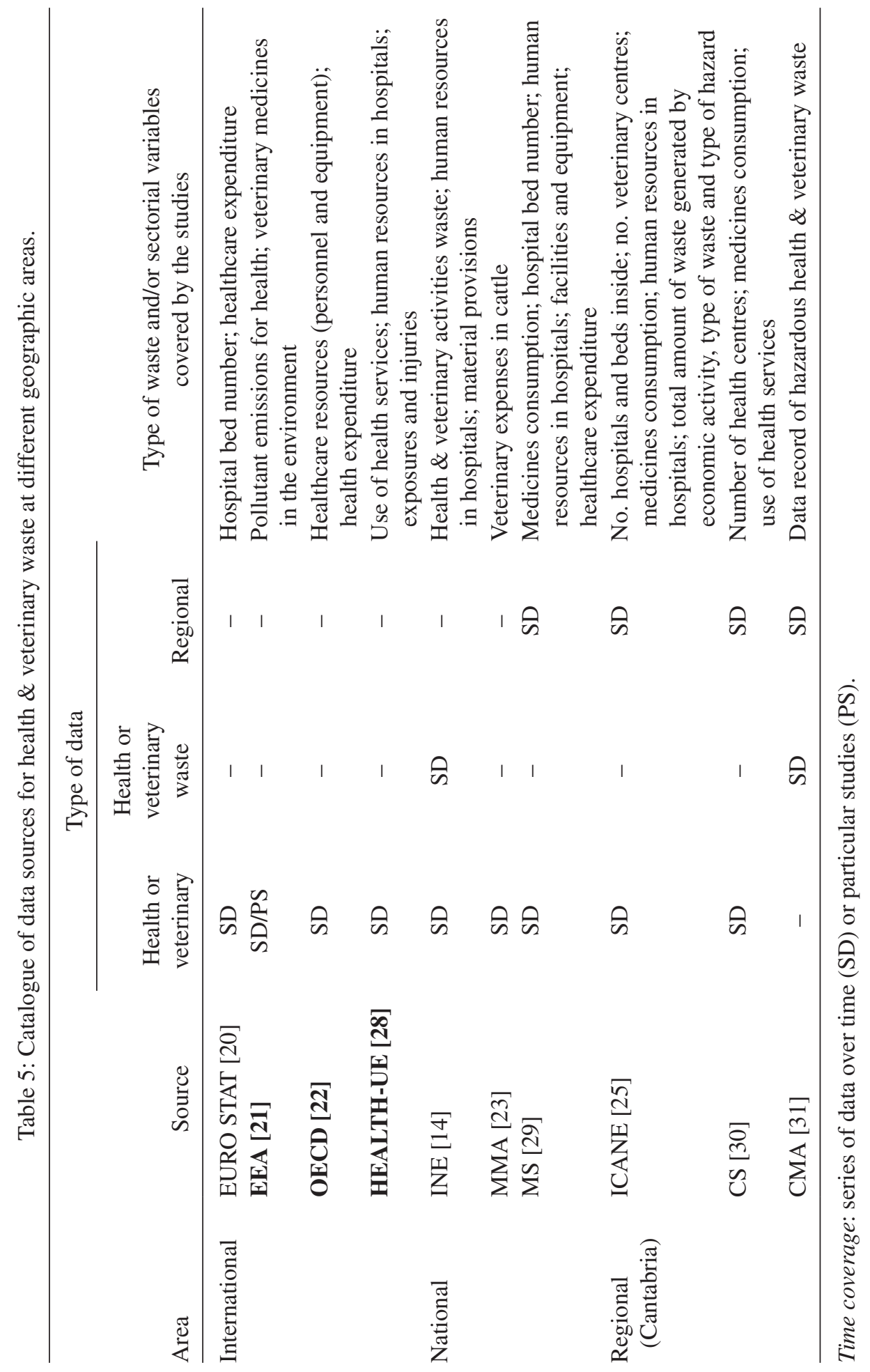


E. Cifrian et al., Int. J. Sus. Dev. Plann. Vol. 9, No. 6(2014)

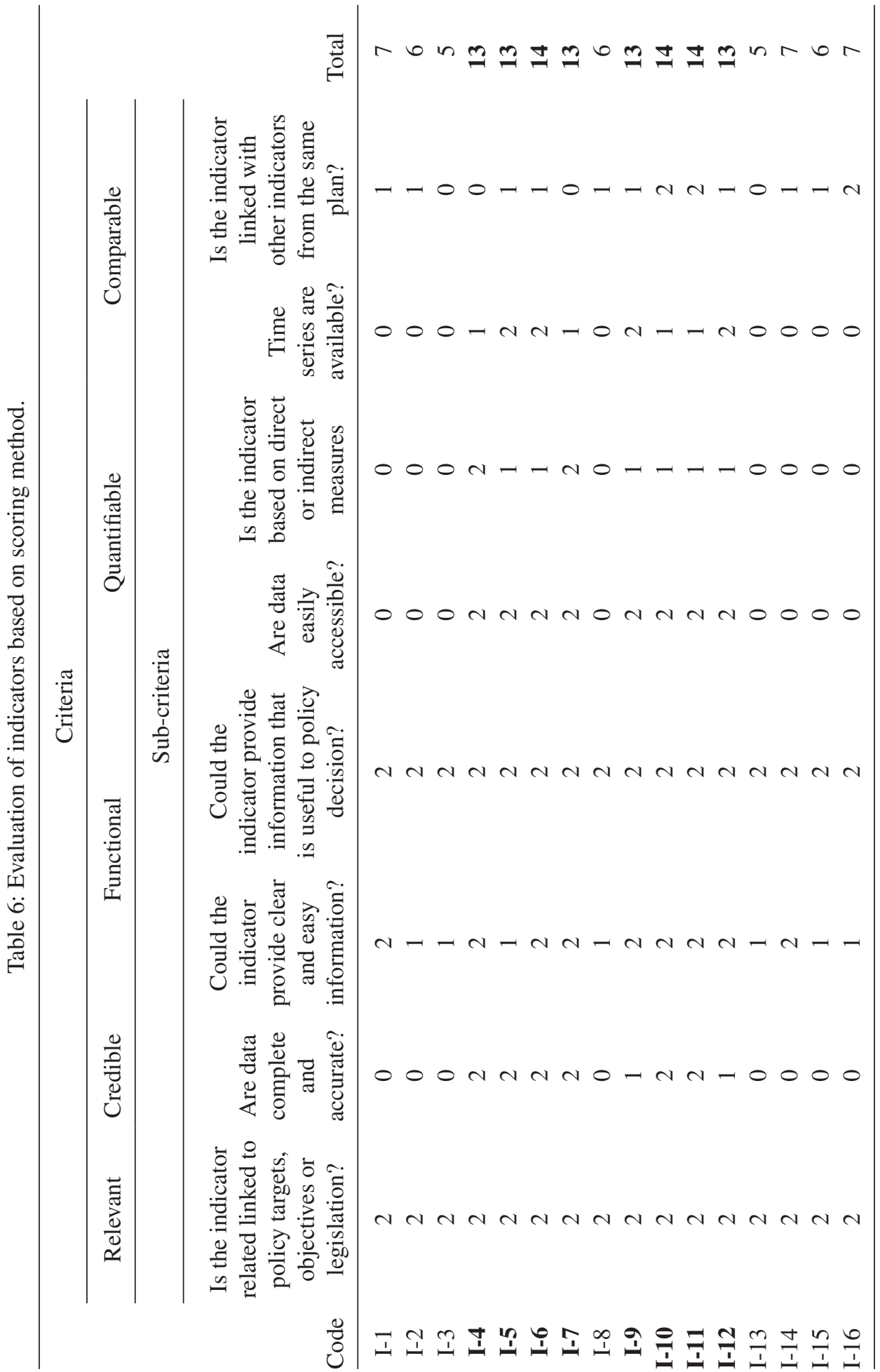


bales/year with $0.70 \mathrm{~kg} / \mathrm{bale}$ of average weight). These data have been remained stable in recent years.

In contrast, the use of biodegradable plastics is zero at the moment. Despite the positive aspects of these plastics, such as minimizing the environmental impact or not having to be collected, they have a very high cost compared with conventional plastics (50 times higher), so it is still not competitive. The objective proposed in the regional plan of increasing the use of biodegradable plastic is not achieved, and no actions are implemented currently to improve the situation.

\subsubsection{Level of generation of phytosanitary packaging waste (I-5)}

This indicator assesses the generation of phytosanitary packaging waste through ecologic farming practices. Plant protection products contain substances classified as hazardous and it is necessary to take appropriate safety measures and compliance with the doses and times indicated on the container security which is usually impregnated with traces of the product. Ecological agricultural practices avoid the use of these products, so that through the hectares for this agriculture that replaces the traditional one, the reduction of the packaging generation can be estimated.

The indicator is calculated as the number of hectares under organic farming and integrated production in Cantabria compared with total hectares of existing farms. Data are obtained from the Spanish Ministry of Environment [23].

Cantabria agriculture is mainly oriented towards livestock, with a low presence of agriculture. For this reason, the use of pesticides is much lower than in other parts of Spain and is very focused on the use of herbicides. The area used to ecological practices is still small, with a value of $2.3 \%$ of average value in the last 9 years (Fig. 2).

The generation of phytosanitary packaging waste measured through the use of organic farming and integrated production hardly increased in the last four years. It is necessary to evaluate the evolution in the next four years, when the regional plan is in force.

\subsubsection{Rate of useful land to reuse the manure (I-6)}

This indicator looks at the amount of agricultural area that would be necessary to reuse the manure generated by livestock without causing environmental damage.

Farms have traditionally used manure as agricultural fertilizer due to its high nutrient content. This practice often creates pollution of soil and water mainly due to the nitrate content of manure. It is a valid practice for small farms that have not surface problems using manure, but not for intensive and large farms that have not enough productive soil to spread it [33].

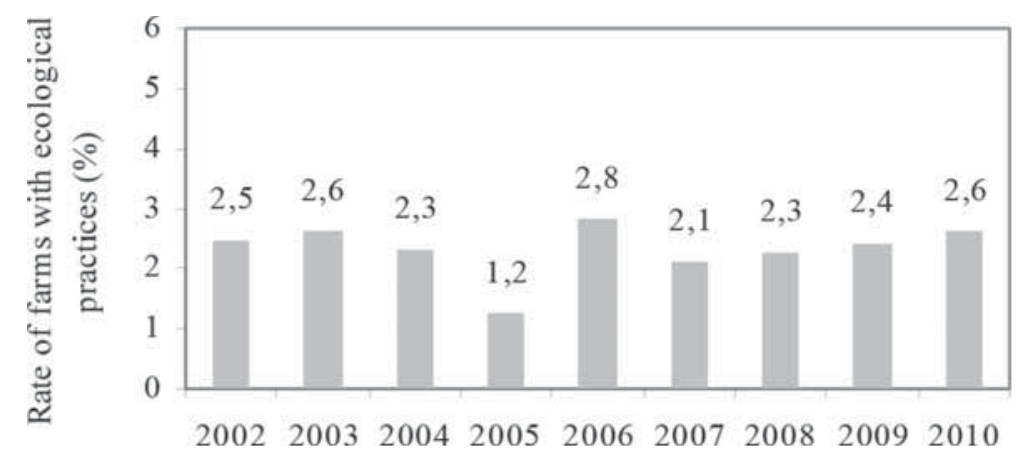

Figure 2: Percentage of ecological farming practices. 


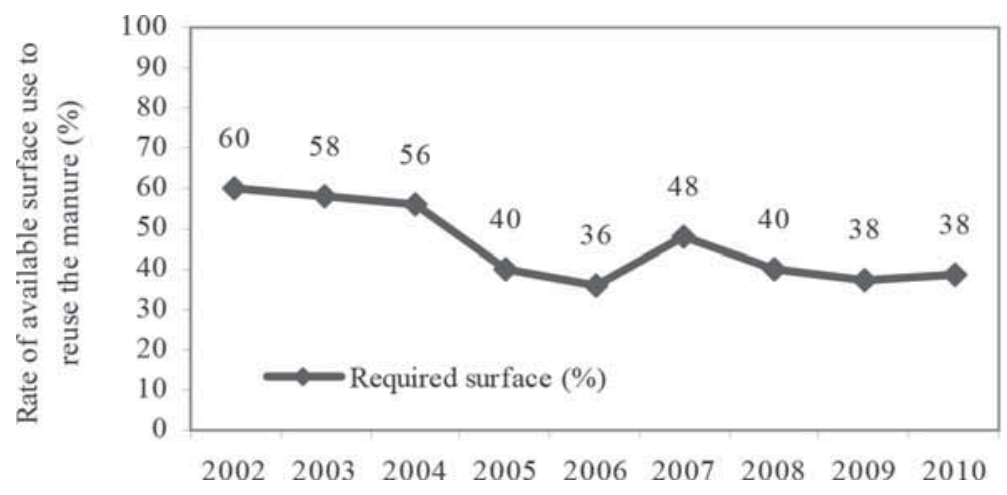

Figure 3: Surface to reuse the manure.

Therefore, a controlled management of this waste is required to prevent environmental degradation and reduce dumping waste without any control. For that, it is required to study the availability of land for livestock-farm manure, being necessary to ensure correct application rates to avoid soil contamination.

For its calculation, the data of available land are taken from the Yearbook of Statistics of the Spanish Ministry of Environment [34]. Also, the area required to take the manure is calculated from the number of cattle from the same source, by charging rates of manure generation and nitrogen content. Once the generated amount of nitrogen is calculated, with the nitrogen application limit of $170 \mathrm{kgN} /$ ha/year defined by Directive 91/676/EEC [35], the amount of required area that would be needed in the region to absorb the amount of manure generated is calculated.

The temporal evolution of I-6 (Fig. 3) shows that the required area to take the manure generated is less than the potential areas of use in Cantabria. The results are calculated at regional level and they could not reflect the local reality of some intensive operations in some municipalities. The objective of enabling enough surfaces to value manure is achieved at regional level. It is necessary to ensure that at farm level it is achieved too.

\subsubsection{Rate of waste recycling in food industry (I-7)}

Food processing activities produce in Europe large amounts of by-products and waste (about $2.510^{8}$ ton/year) [36] along with relevant amounts of high COD effluents. Such waste streams are only partially valorized at different value-added levels (spread on land, animal feed, composting), whereas the main volumes are managed as waste of environmental concern, with relevant negative effects on the overall sustainability of food processing industry [37]. Cantabria is a region with few food industries compared with national level, being distributed mainly in the north part of the region. Among the 466 food industries, the $11 \%$ are dedicated to dairy sector, being a total of 43 dairies specialized in cheese. The cheese industry, although not very important in number, is involved in environmental issues, mainly due to the large amount of whey that is generated, with a large organic load to the water treatment plants. Whey is the liquid that separates from milk when it is coagulated to obtain cheese. It contends a high amount of proteins and lactose that can become pollutants when the liquid is thrown into the environment without any treatment. However, the whey treatment would provide marketable products with food and pharmaceutical applications. This indicator examines the reuse of whey: a significant percentage of food industries do not manage the streams' wastes [27].

The results show that the 43 dairies in Cantabria produce a total of 65,118 1/day of whey with more than $57 \%$ discharged to the environment without any pre-treatment (Fig. 4). The objective of 


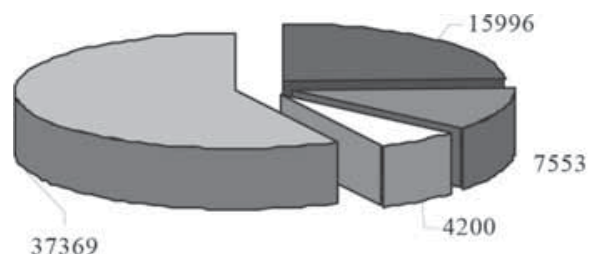

$\square$ Internal management

口 Farm Animal Feed

$\square$ Downstream applications

$\square$ Disposal (rivers, sea, subsoil,...)

Figure 4: Whey management (1/day).

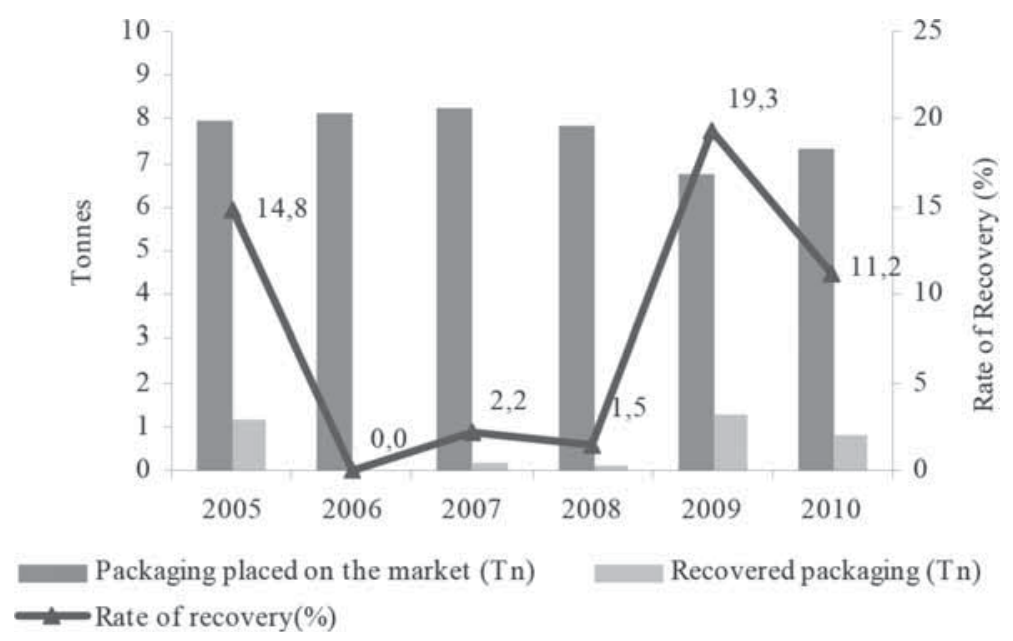

Figure 5: Recovery of phytosanitary packaging.

reusing $100 \%$ cheese whey is not achieved. Legislation forbids the disposal of this waste; therefore it is necessary to monitor this objective closer.

\subsubsection{Rate of recovery of phytosanitary packaging waste (I-9)}

This indicator measures the amount of packaging waste recovered, compared with the total packaging waste generated in Cantabria. These data are obtained from SIGFITO [24], an integrated management system for this waste stream. The I-9 indicator takes into account the recovery of the empty containers and the unopened containers.

The phytosanitary packaging waste rate of recovery vary from $0.0 \%$ to $19.3 \%$ in the $2005-2010$ studied period (Fig. 5); this high variability is due to the punctual recovery campaigns with time and spatial constraints (short collection period and only 5 points to collect in Cantabria). This situation makes that the target of the plan of increasing recovery rate of phytosanitary packaging waste is not met.

\subsubsection{Rate of recovery of residual forest biomass (RFB) (I-10)}

This indicator measures the amount of RFB recovered in relation to the amount generated. The recovery of RFB is an effective measure to avoid a large amount of fires and the spread of pests.

To calculate the indicators only data from public forests are available, total area of 257,442 hectare, which represent $71.62 \%$ of total forest in the region. The generation of RFB is an estimated quantity calculated by the Department of Rural Development, Livestock, Fisheries and Biodiversity of the Regional Government of Cantabria [26] as the volume of firewood and wood volume with 


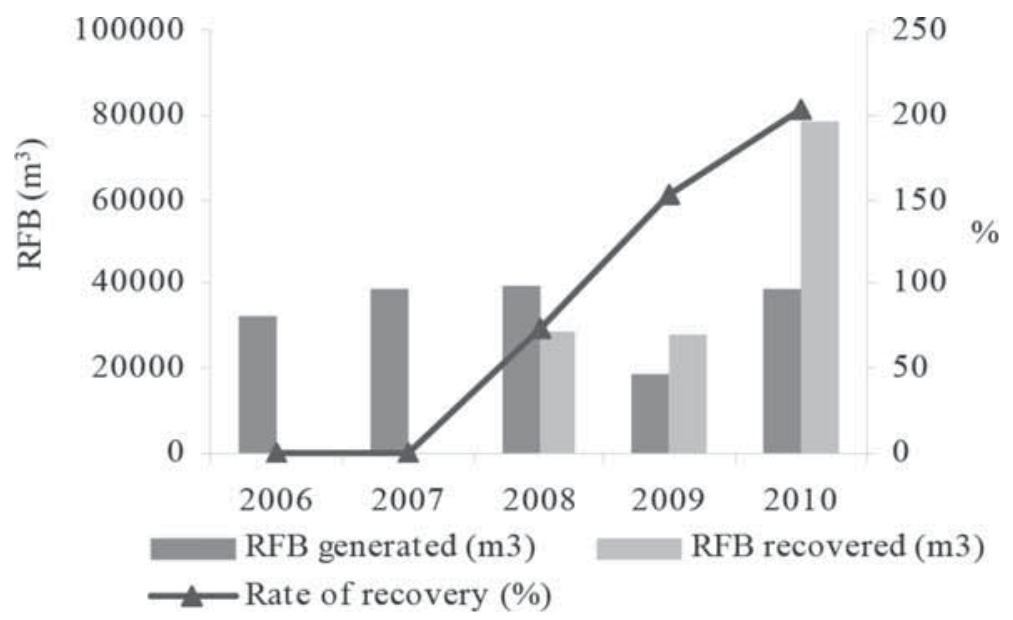

Figure 6: Recovery of residual forest biomass.

bark in public forest cut down; the RFB quantity recovered are reported by different companies that are subsidized by the Department of Biodiversity for this way of management.

The generation data remain constant over the years studied, with the exception of 2009, which was less cutting of eucalyptus, because they were imported from other European regions where had severe storms and their respective governments subsidized their collection. The recovery of RFB in Cantabria began in 2008 and in the year 2010 have increased significantly; the quantity of RFB recovered in this year doubled the amount of previous years (Fig. 6) due to changes in the regional regulations that affects the way of subsidizing the collection, obtaining higher values. The objective proposed in the plan of increasing recovery rates of RFB has been met; however, the objective of establishing monitoring mechanism to provide reliable information is not achieved considering that only data from public forest are available.

\subsubsection{Rate of energy production from forest biomass (RFB) (I-11)}

This indicator measures the amount of RFB subjected to energy recovery processes. The energy recovery from forest biomass implies a reduction of fuel consumption and $\mathrm{CO}_{2}$ emissions.

The regional Government suppose that the recovered RFB is all for energy production; therefore, the amount of RFB to produce energy has increased significantly in 2010 compared with 2008 and $2009(+270 \%)$ due to the fact the collection has increased too (see I-10). The objective of increasing the energy production from RFB is achieved.

Apart from these data, there are different industrial biomass recovery plants in the region of using this type of waste but no data of these installations are available.

\subsubsection{Selective waste collection of health \& veterinary waste (I-12)}

This indicator relates the amount of recovered health \& veterinary waste with the generated amount (only hazardous ones). The hazardous character of these streams creates the need of segregation at source and proper waste management to avoid risk for human health and for the environment.

The recovery of hazardous health waste (Fig. 7a) is higher than the estimated waste generation; this is mainly due to most of medical wastes are classified as similar to municipal waste but some of them are managed as health waste instead of managed it in the municipal channel. The veterinary waste management has been carried out properly, reaching high values of rate of recovery (Fig. 7b). 
The proper waste segregation, stated as objective of the waste Plan, is not met due to the joint management of health and similar to municipal waste streams.

\subsection{SWOT analysis}

Once the most promising indicators were developed, a SWOT analysis is proposed to study the current status of all the 16 feasible indicators (Tables 7 and 8).

The SWOT analysis shows that there are more Threats (T) and Weakness (W) (31 and 24, respectively, for Primary Sector and 13 and 15 for Health \& Veterinary Services) than Opportunities (O) and Strengths (S) (15 and 8 for Primary Sector and 7 and 3 for Health \& Veterinary Services). In the future, the lack of data for developing the indicators and the waste management status will be improved due to different ongoing activities: integrated management systems implementation, economic aids, educational campaigns \& specific courses and particular studies.

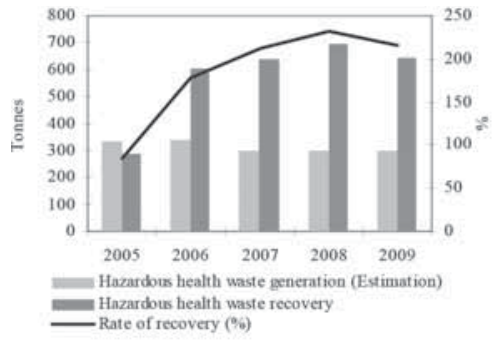

(a)

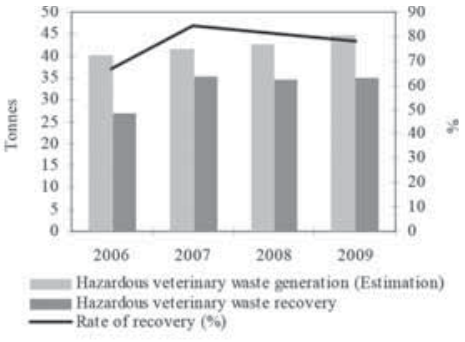

(b)

Figure 7: Recovery of (a) health waste $\&$ veterinary waste.

Table 7: SWOT analysis for primary sector waste indicators.

\begin{tabular}{|c|c|c|c|c|c|c|c|c|c|c|c|}
\hline \multirow[b]{2}{*}{ SWOT analysis } & \multicolumn{11}{|c|}{ Indicator } \\
\hline & $\mathrm{I}-1$ & $\mathrm{I}-2$ & $\mathrm{I}-3$ & I-4 & I-5 & I-6 & I-7 & $\mathrm{I}-8$ & I-9 & $\mathbf{I}-\mathbf{1 0}$ & I-11 \\
\hline \multicolumn{12}{|c|}{ External analysis: opportunities $(\boldsymbol{O})$; threats $(\boldsymbol{T})$} \\
\hline Management model established & - & - & - & $\mathbf{T}$ & - & $\mathbf{T}$ & $\mathbf{T}$ & $\mathrm{T}$ & $\mathbf{O}$ & $\mathbf{T}$ & $\mathbf{T}$ \\
\hline Integrated management systems & - & - & - & $\mathbf{O}$ & $\mathbf{O}$ & $\mathbf{T}$ & $\mathbf{T}$ & - & $\mathbf{O}$ & $\mathbf{T}$ & $\mathbf{T}$ \\
\hline $\begin{array}{l}\text { Existing infrastructure (recycling or } \\
\text { treatment plants) }\end{array}$ & - & - & - & $\mathbf{T}$ & - & $\mathbf{T}$ & $\mathbf{T}$ & - & $\mathbf{O}$ & - & $\mathbf{T}$ \\
\hline Collection points & - & - & - & $\mathbf{T}$ & & $\mathbf{T}$ & - & - & $\mathbf{T}$ & $\mathbf{T}$ & $\mathrm{T}$ \\
\hline Subsidies/economic aids & $\mathrm{O}$ & - & $\mathrm{O}$ & - & $\mathbf{O}$ & $\mathbf{O}$ & $\mathbf{T}$ & - & - & $\mathbf{O}$ & $\mathbf{O}$ \\
\hline Courses/training programs & - & $\mathrm{O}$ & $\mathrm{T}$ & - & $\mathbf{T}$ & $\mathbf{O}$ & $\mathbf{T}$ & - & - & $\mathbf{T}$ & $\mathbf{T}$ \\
\hline Campaigns & - & $\mathrm{O}$ & $\mathrm{T}$ & $\mathbf{T}$ & $\mathbf{T}$ & $\mathbf{O}$ & $\mathbf{T}$ & - & - & $\mathbf{T}$ & $\mathbf{T}$ \\
\hline \multicolumn{12}{|c|}{ Internal analysis: strengths $(\boldsymbol{S}) ;$ weaknesses $(\boldsymbol{W})$} \\
\hline Specific legislation & $\mathrm{W}$ & - & - & $\mathbf{W}$ & $\mathbf{W}$ & $\mathbf{W}$ & $\mathbf{W}$ & $\mathrm{W}$ & $\mathbf{W}$ & $\mathbf{W}$ & $\mathbf{W}$ \\
\hline Specific waste plan & $\mathrm{W}$ & - & - & $\mathbf{W}$ & $\mathbf{W}$ & $\mathbf{W}$ & $\mathbf{W}$ & - & $\mathrm{W}$ & $\mathrm{W}$ & $\mathrm{W}$ \\
\hline Regional register & $\mathrm{W}$ & $\mathrm{W}$ & $\mathrm{W}$ & - & $\mathbf{S}$ & $\mathbf{S}$ & $\mathbf{W}$ & $\mathrm{W}$ & $\mathbf{S}$ & $\mathbf{W}$ & $\mathbf{W}$ \\
\hline Particular studies & $\mathrm{S}$ & - & - & - & - & $\mathbf{S}$ & $\mathbf{S}$ & - & - & $\mathbf{S}$ & $\mathbf{S}$ \\
\hline
\end{tabular}


Table 8: SWOT analysis for health \& veterinary sector waste indicators.

\begin{tabular}{lccccc}
\hline & \multicolumn{5}{c}{ Indicator } \\
\cline { 2 - 6 } SWOT analysis & I-12 & I-13 & I-14 & I-15 & I-16 \\
\hline External analysis: opportunities $(\boldsymbol{O})$; threats $(\boldsymbol{T})$ & & & & & \\
Management model established & T & - & $\mathrm{T}$ & $\mathrm{T}$ & $\mathrm{T}$ \\
Authorized managers & $\mathbf{O}$ & - & - & $\mathrm{T}$ & $\mathrm{O}$ \\
Existing infrastructure (recycling or treatment plants) & $\mathbf{O}$ & - & - & $\mathrm{T}$ & $\mathrm{O}$ \\
Subsidies/economic aids & - & $\mathrm{T}$ & - & $\mathrm{T}$ & - \\
Staff training & $\mathbf{O}$ & $\mathrm{O}$ & $\mathrm{O}$ & - & - \\
Campaigns & T & $\mathrm{T}$ & $\mathrm{T}$ & $\mathrm{T}$ & $\mathrm{T}$ \\
Internal analysis: strengths $(\boldsymbol{S})$; weakness $(\boldsymbol{W})$ & & & & & \\
Specific legislation & $\mathrm{S}$ & - & $\mathrm{S}$ & $\mathrm{W}$ & $\mathrm{S}$ \\
Specific waste plan & W & - & $\mathrm{W}$ & $\mathrm{W}$ & $\mathrm{W}$ \\
Regional register & W & W & W & W & W \\
Particular studies & W & W & W & W & W \\
\hline
\end{tabular}

To complete the methodological process of developing indicators a set of strategies and actions are proposed based on SWOT results. These actions must be feasible, improving the current situation of the indicators and leading to the implementation of changes. Therefore, in order to improve the indicators related to the primary sector, health \& veterinary services, specific actions and activities have been described in Tables 9 and 10 .

To implement the Primary Sector, Health \& Veterinary Services set of indicators coordination with different regional administrations (livestock and agriculture, environment, biodiversity, forestry, health) has been required in order to find most reliable sources of data. The present article shows the main results of the project that systematizes and centralizes data collection of all those variables and data sources selected, through the use of 'ad-hoc' create forms. Furthermore, the implementation of series of records was necessary to enable the collection of data for different variables for which no information was available. This information must be updated annually [38]. The management of information is carried out within the project team that includes two researchers and two project managers. The researchers have more than 5-year experience in waste indicators research, while the project managers are involved in the waste industry for more than 20 years, particularly with more than 8-year experience in waste information management and decision-making tools. The obtained and analysed information is communicated to the politicians, who are responsible for creating the right policies to improve the situation.

\section{CONCLUSIONS}

A set of indicators has been developed to assess the objectives proposed on the Primary sector, Health \& veterinary services Waste Plan 2010-2014 (PHWP). The methodology for the development of indicators is divided into five stages, including synthesis, analysis, evaluation, application and interpretation, and SWOT analysis. As a result, 16 indicators related to flows of waste have been obtained.

The specific analysis of the information sources shows that there are many statistics about agriculture and agri-environmental data but on the contrary a lack of regional data about the studied waste streams. In the same manner, there are many statistics about health $\&$ veterinary services data but 
Table 9: Strategies and action plans for primary sector waste indicators.

\begin{tabular}{|c|c|c|}
\hline Actions & Activities & Responsible (framework) \\
\hline Approving regulations & $\begin{array}{l}\text { Unification of Spanish regulations for } \\
\text { phytosanitary packaging waste }\end{array}$ & MMA [21] (national) \\
\hline Create specific plans & $\begin{array}{l}\text { Specific plans for manure management } \\
\text { and for storage facilities }\end{array}$ & CDR [25] (regional) \\
\hline $\begin{array}{l}\text { Establishing } \\
\text { management models }\end{array}$ & $\begin{array}{l}\text { Development of models for extensive or } \\
\text { semi-extensive livestock }\end{array}$ & CDR [25] (regional) \\
\hline \multirow[t]{2}{*}{ Subsidies } & Setting aids for farms modernization & CDR [25] (regional) \\
\hline & $\begin{array}{l}\text { Setting aids for the development of residual } \\
\text { forest biomass extraction in the mountains } \\
\text { or forest land in the region }\end{array}$ & CDR [25] (regional) \\
\hline Economic agreements & $\begin{array}{l}\text { Establishment of economic agreements } \\
\text { between the government and agricultural } \\
\text { and livestock manufacturers to get a good } \\
\text { management }\end{array}$ & CDR [25] (regional) \\
\hline \multirow[t]{2}{*}{ Signing of agreements } & $\begin{array}{l}\text { Agreements with non-profit organizations } \\
\text { for agricultural plastic }\end{array}$ & NPOWM (company) \\
\hline & $\begin{array}{l}\text { Increasing the phytosanitary packaging } \\
\text { waste collection points }\end{array}$ & NPOWM (company) \\
\hline \multirow{2}{*}{$\begin{array}{l}\text { Constructing } \\
\text { infrastructure or } \\
\text { adapting facilities }\end{array}$} & $\begin{array}{l}\text { Promoting the existing projects to create } \\
\text { biomass recovery plants }\end{array}$ & CDR [25] (regional) \\
\hline & $\begin{array}{l}\text { Adequacy of collection sites for plastics } \\
\text { for agricultural use }\end{array}$ & AC (company) \\
\hline \multirow[t]{2}{*}{ Campaigns and training } & $\begin{array}{l}\text { Agricultural and environmental practices, } \\
\text { particularly on waste management in the } \\
\text { primary sector; training in manures } \\
\text { management; information and training } \\
\text { on the benefits of using whey } \\
\text { Spreading management practices to reduce } \\
\text { the agrochemicals use }\end{array}$ & CDR [25] (regional) \\
\hline & $\begin{array}{l}\text { Finance by non-profit organizations for } \\
\text { waste management }\end{array}$ & NPOWM (company) \\
\hline \multirow[t]{3}{*}{ Production of records } & $\begin{array}{l}\text { Creating a regional annual record of } \\
\text { forest waste generation, collection } \\
\text { and final disposal }\end{array}$ & CDR [25] (regional) \\
\hline & Creating a record of food industry waste & CDR [25] (regional) \\
\hline & $\begin{array}{l}\text { Surveying the farmers to estimate } \\
\text { the number of manure facilities }\end{array}$ & PFR [36] (regional) \\
\hline Control and monitoring & $\begin{array}{l}\text { Control and monitoring of facilities } \\
\text { to ensure the proper management of whey }\end{array}$ & CDR [25] (regional) \\
\hline
\end{tabular}

NPOWM, non-profit organizations for waste management; AC, agricultural cooperatives. 
Table 10: Strategies and action plans for Health \& Veterinary Services Waste Indicators.

\begin{tabular}{|c|c|c|}
\hline Actions & Activities & $\begin{array}{l}\text { Responsible } \\
\text { (framework) }\end{array}$ \\
\hline Approving regulations & Specific regulations for veterinary waste & CMA [30] (regional) \\
\hline Create specific plans & $\begin{array}{l}\text { Plans by medical and veterinary centres in order } \\
\text { to manage waste properly }\end{array}$ & CMA [30] (regional) \\
\hline $\begin{array}{l}\text { Establishing } \\
\text { management models }\end{array}$ & $\begin{array}{l}\text { Specific classification of medical waste, in order } \\
\text { to strengthen and unify the separation at source }\end{array}$ & $\begin{array}{l}\text { CMA [30]/HC } \\
\text { (regional; company) }\end{array}$ \\
\hline $\begin{array}{l}\text { Subsidies } \\
\text { Signing of agreements }\end{array}$ & $\begin{array}{l}\text { Subsidizing studies and projects aimed at } \\
\text { prevention of waste }\end{array}$ & CMA [30] (regional) \\
\hline Economic agreements & $\begin{array}{l}\text { Contacting with non-profit organizations for } \\
\text { waste management to implement the selective } \\
\text { collection of materials in the health field, such } \\
\text { as paper and cardboard }\end{array}$ & $\begin{array}{l}\text { CMA [30]/NPOWM } \\
\text { (regional; company) }\end{array}$ \\
\hline $\begin{array}{l}\text { Constructing } \\
\text { infrastructure or } \\
\text { adapting facilities }\end{array}$ & $\begin{array}{l}\text { Establishment of infrastructure conditions for } \\
\text { proper storage of waste in health centres }\end{array}$ & CMA [30] (regional) \\
\hline Campaigns and training & Campaigning to improve the segregation of waste & CMA [30] (regional) \\
\hline Production of records & Inventory of generated and managed waste & $\begin{array}{l}\text { CMA [30]/HC/VC } \\
\text { (regional; company) }\end{array}$ \\
\hline Control and monitoring & $\begin{array}{l}\text { Implementation of campaigns for regular } \\
\text { inspection and control the final management } \\
\text { of waste and verifying the compliance with the } \\
\text { legislation }\end{array}$ & CMA [30] (regional) \\
\hline
\end{tabular}

$\mathrm{HC}$, health centres; VC, veterinary centres; NPOWM, non-profit organizations for waste management.

there is not any one about the waste generation. The availability of data for indicators has been evaluated through scoring method using different criteria as relevance, credibility, functionality, quantifiable and comparability of the indicator. The results obtained show that only eight indicators obtain more than 8 points over 16 in the evaluation. The SWOT analysis for each indicator shows the current situation and defines the changes and modifications necessary to improve the indicators based on an information system in the waste area in Cantabria. Based on the results of the SWOT analysis, a strategic mechanism composed of actions and specific activities has been proposed.

The applied methodology can be successfully used as a tool for decision-making about PHWP and can be useful to improve the data and sources of the proposed indicators.

\section{REFERENCES}

[1] Aguirre, M.A., Los sistemas de indicadores ambientales y su papel en la información e integración del medio ambiente/Environmental indicator set and their role in information and integration of environment. Libro de ponencias del I Congreso De Ingeniería Civil, Territorio y Medio Ambiente/Book of Abstracts of the First Congress of Civil Engineering, Planning and the Environment, Madrid, pp. 1231-1256, 2002. 
[2] Qiu, H.J., Zhu, W.B., Wang, H.B. \& Cheng, X. Analysis and design of agricultural sustainability indicators system. Agricultural Sciences in China, 6(4), pp. 475-486, 2007. doi: http:// dx.doi.org/10.1016/s1671-2927(07)60072-8

[3] EEA, European Environmental Agency. EEA core set of indicators, Guide. EEA Technical Report No. 1, 2005. doi: http://dx.doi.org/10.1007/bf02986943

[4] EEA, European Environment Agency. Environmental indicators: typology and overview. Smeets, E. \& Weterings, R., (eds). EEA Technical Report No. 25, pp. 19, 1999.

[5] EEA, European Environment Agency. Assessment of information related to waste and material flows: a catalogue of methods and tools. EEA Technical Report No. 96, pp. 63, 2003.

[6] Cifrian, E., Coz, A., Viguri, J. \& Andres, A. Indicators for valorisation of municipal solid waste and special waste. Waste and Biomass Valorization, 1, pp. 479-486, 2010. doi: http://dx.doi. org/10.1007/s12649-010-9043-5

[7] Cifrian, E., Galán, B., Andrés, A. \& Viguri, J. Material flow indicators and carbon footprints for MSW management systems: analysis and application at regional level, Cantabria, Spain. Resources, Conservation and Recycling, 68, pp. 54-66, 2012. doi: http://dx.doi.org/10.1016/j. resconrec.2012.08.007

[8] Giljum, S., Burger, E., Hinterberger, F., Lutter, S. \& Bruckner, M. A comprehensive set of resources use indicators from the micro to the macro level. Resources, Conservation and Recycling, 55, pp. 300-308, 2011. doi: http://dx.doi.org/10.1016/j.resconrec.2010.09.009

[9] Niemejer, D. \& Groot, R. A conceptual framework for selecting environmental indicator sets. Ecological Indicators, 8, pp. 14-25, 2008. doi: http://dx.doi.org/10.1016/j.ecolind.2006.11.012

[10] Yabar, H., Hara, K. \& Uwasu, M. Comparative assessment of the co-evolution of environmental indicator systems in Japan and China. Resources, Conservation and Recycling, 61, pp.43-51, 2012. doi: http://dx.doi.org/10.1016/j.resconrec.2011.12.012

[11] EEA, European Environment Agency. Environmental indicator report 2012. Ecosystem resilence and resource efficiency in green economy in Europe. Publications Office of the European Union, Copenhagen, pp. 156, 2012. doi:

[12] EC, European Commission Directive 2008/98/EC of the European Parliament and of the Council of 19 November 2008 on waste and repealing certain directives (Waste Framework Directive). Official Journal L, 312, 22/11/2008, p. 3.

[13] BOC, Boletín Official de Cantabria/Official Gazette of Cantabria, Order 15/2010, of 4 March, 2010-2014 Cantabria Waste Sectorial Plans. BOC, 66, pp. 12005-12198, 2010.

[14] INE, Instituto Nacional de Estadística/National Institute of Statistics, www.ine.es.

[15] Yang, X., Ikehata, K., Lerner, R., Hu, Y., Josyula, K., Chang, S.X. \& Liu, Y., Agricultural wastes. Water Environment Research, 82(10), pp. 1396-1425, 2010. doi: http://dx.doi.org/10. 2175/106143010x12756668801338

[16] Cifrian, E., Perez, L., Dosal, E., Viguri, J. \& Andres, A. Primary sector waste indicators for regional planning. WIT International Conference of Sustainable Development and Planning, England, 2011. doi: http://dx.doi.org/10.2495/sdp110041

[17] EEA, European Environment Agency. The IRENA indicator report: agriculture and environment in EU-15, 2005.

[18] Yli-Viikari, A., Hietala-Koivu, R., Huusela-Veistola, E., Hyvönen, T., Perälä, P. \& Turtola, E., Evaluating agri-environmental indicators (AEIs) - use and limitations of international indicators at national level. Ecological Indicators, 7, pp. 150-163, 2007. doi: http://dx.doi. org/10.1016/j.ecolind.2005.11.005

[19] Yang, Y., SWOT-TOPSIS integration method for strategic decision, International Conference on E-Business and E-Government, 2010. doi: http://dx.doi.org/10.1109/icee.2010.399 
[20] EUROSTAT, http://epp.eurostat.ec.europa.eu/portal/page/portal/eurostat/home.

[21] EEA, European Environment Agency, www.eea.europa.eu/es. doi: http://dx.doi.org/ 10.1002/9780470057339.vae050

[22] OECD, Organisation for Economic Co-operation and Development, www.oecd.org. doi: http:// dx.doi.org/10.4324/9780203875773

[23] MMA, Ministerio de Medio Ambiente, Medio Rural y Marino/Spanish Ministry of Environment, www.marm.es.

[24] SIG, Sigfito Agroenvases, www.sigfito.es.

[25] ICANE, Instituto Cántabro de Estadística/Institute of Statistics of Cantabria, www.icane.es.

[26] CDR, Consejería de Desarrollo Rural, Ganadería, Pesca y Biodiverisdad del Gobierno Regional de Cantabria/Department of Rural Development, Livestock, Fisheries and Biodiversity of the Regional Government, www.cantabria.es/web/consejeria-de-desarrollo-rural-ganaderia-pescay-biodiversidad.

[27] CIFA, Centro de Investigación y Formación Agrarias/Centre of Agricultural Research and training, www.cifacantabria.org.

[28] Health-UE, Public Heath Portal of the European Union, http://ec.europa.eu/health-eu.

[29] MS, Ministerio de Sanidad/Spanish Ministry of Health, www.msps.es.

[30] CS, Consejería de Sanidad y Servicios Socialess del Gobierno Regional de Cantabira/ Department of Health and social services of Regional Government, www.saludcantabria.org.

[31] CMA, Consejería de Medio Ambiente del Gobierno Regional/Department of Environment of Regional Government, www.medioambientecantabria.com.

[32] Kurtz, J., Jackson, L.E. \& Fisher, W.S., Strategies for evaluating indicators based on guidelines from the Environmental Protection Agency's Office of Research and Development. Ecological Indicators, 1, pp. 49-60, 2001. doi: http://dx.doi.org/10.1016/s1470-160x(01)00004-8

[33] Basnet, B.B., Apan, A.A. \& Raine, S.R. Selecting suitable sites for animal waste application using a raster GIS. Environmental Management, 28(4), pp. 519-531, 2001. doi: http://dx.doi. org/10.1007/s002670010241

[34] MMA, Ministerio de Medio Ambiente, Medio Rural y Marino/Spanish Ministry of Environment. Yearbook of statistics. www.marm.es/es/estadistica/temas/anuario-de-estadistica.

[35] EC, European Council Directive 91/676/EEC of 12 December 1991 concerning the protection of waters against pollution caused by nitrates from agricultural sources. Official Journal L, 375, 31/12/1991, pp. 0001-0008.

[36] Awarenet. Handbook of the prevention and minimisation of waste and valorisation of byproducts in European agro-food industries, 2004.

[37] Federici, F., Fava, F., Kalogerakis, N. \& Mantzavinos, D. Valorisation of agro-industrial byproducts, effluents and waste: concept, opportunities and the case of olive mill wastewaters. Journal of Chemical Technology and Biotechnology, 84, pp. 895-900, 2009. doi: http://dx.doi. org/10.1002/jctb.2165

[38] PFR, Punto Focal de Residuos de Cantabria/Focal Point on Waste of Cantabria http://prf. medioambientecantabria.es. 